\title{
Impact of Liquidity Ratio on Profitability of Firm: An Empirical Evidence from Automobile Industry of Pakistan
}

\author{
Waqar Mustafa Waqar Ahmed Sethar Adnan Pitafi \\ Shah Muhammad Kamran* \\ Mehran University - Institute of Science, Technology and Development, Pakistan.
}

\begin{abstract}
Pakistan automobile industry was experiencing a boom from the last two decades, but currently it is facing footraces due to financial suffering in the Pakistan market. This study is an attempt to investigate the impact of liquidity on profitability either positively or negatively. Liquidity of a firm can be measured through different ratios e.g. current ratio, cash ratio, and quick ratio, whereas profitability or financial performance of firm can be scaled with the proxies like return on equity and return on assets. Panel data of 5 years of 12 automobile firms listed in PSX is used for the analysis. Fixed effect model and random effect model were used for empirical investigation and Hausman test was employed to choose appropriate model between fixed and random effect. Results of the analysis revealed that the liquidity (quick ratio) positively effect on profitability; return on assets (ROA). However, there is a negative relationship between liquidity (current ratio and cash ratio) with return on
\end{abstract} asset.

Keywords: Profitability, Liquidity, Return on assets, quick ratio, current ratio, cash ratio financial performance. DOI: $10.7176 /$ RJFA/10-22-16

Publication date: November $30^{\text {th }} 2019$

\section{INTRODUCTION}

The automobile industry is the significant driver of Pakistan economy. It plays a vital role in industrial as well as overall economic growth. The automobile industry is one of the largest revenue generating industry in Pakistan, where different listed companies manufacture variety of products like car, rickshaw, trucks, buses and bikes. Listed companies in Pakistan Stock Exchange (PSX) include national and multi-national both and are assembling different products for different sections of market. Financial stability of these companies always attract investors by offering good return on investments and dividends (Öztürk \& Karabulut, 2018). For making investments profitable, investors remain curious about the company's financial condition and financially stable companies can remain viable in the current and log run economic scenario so making their investments less risky (Mathur \& Agarwal , 2016)

For analysis of profitability of any company, management as well as investors look into liquidity ratios. Liquidity ratios includes; current ratio, cash ratio, and quick ratio, and it indicates the conversion of assets into cash and it also measure the ability of a firm to meet short-term liabilities. Liquidity administration realized through the current use of assets (Robinson et al., 2015). These liquidity ratios interpret the profitability and ability to generate profit in future. Profitability refers to the firm's ability to generate revenue using complete services \& resources like capital, sales, cash, number of workers, and the number of branches. Profitability of a firm can be measured through different ratios, they are helpful to calculate the company's ability in earnings. Profitability ratio contains net profit margin, return on assets, and return on equity (Husna \& Desiyanti, 2016).

This study will help to determine the impact of liquidity on profitability such as; how liquidity crisis could make a negative impact on firm's income and a sufficient liquidity ratio can positively affect revenue or profit of the organization. Previous researches on the impact and relationship between liquidity and profitability shows mixed results (Umobong, 2015; Malik et al 2016).

This study aims to measure the impact of liquidity ratio on the profitability of the listed automobile firms at PSX, it was also tried to find that is there any significant impact of liquidity ratios on profitability either positive or negative. To fulfill the aim current ratio, quick ratio and cash ratio are used for the analysis. Rest of paper organized as; Introduction followed by Literature review, next is research methodology and results and discussion, last section will cover conclusion and recommendations for future research.

\section{LITERATURE REVIEW}

Many studies on the relationship of liquidity and profitability show different and opposite results; some studies show the positive relationship while other shows negative or no relationship at all between liquidity and profitability. Supriati, et al., (2019) conducted research on 11 food and beverage firms of Indonesia, results of the study showed a significant and positive effect of liquidity towards profitability, study also concluded that liquidity is the most significant factor of profitability and financial performance. Studies of Malik, et al., (2016) and Charmlet, et al., (2018) also concluded that liquidity ratios have positive and significant impact on profitability of banking industry. Their results indicate that liquidity is positively associated with return on assets 
using both measures of bank liquidity, and about return on equity, there is a weak positive relationship between the ratios of liquid assets to total assets. These results are consistent with many previous studies (Sarwat 2017; Paliwal \& Chouhan 2017; Ibrahim 2017; Abdullah \& Jahan 2014; Khidmat \& Rehman 2014; Ruziqa 2013; Balasundaram \& Priya 2013; Ajanthan 2013). Mahmud \& Akhter (2014) in their research conclued that there is no significant relationship between current ratio and return on assets while Noor \& Lodhi (2015) found negative impact of liquidity on firm's profitability (return on assets and return on equity). However, some other studies (khan \& Ali, 2016; Ahmad, 2016; Lartey, et al., 2013) on the banking industry found a weak positive impact of liquidity on profitability, these studies suggest that the banks should measure and rearrange their plans for working liquidity, this will not increase earnings on stakeholder's equity but will also increase the use of the resources of the bank.

There are some studies which showed varying impact e.g. positive, negative, insignificant, of different liquidity ratios on proxies of profitability. Mohanty \& Mehrotra, (2018) conducted research of 28 listed SMEs in Bombay, result of the study showed that even if the correlation between liquidity ratios and profitability is negative even then they can positively impact the financial performance of the firm. According to Nazish and Shehla (2017) there is a significantly negative relationship between cash gap and return on assets while the current ratio has a significant positive impact of profitability. Furthermore, results indicate that sales and assets has a significant positive association with profitability. The current ratio and total assets show a positive and significant relationship with net operating income, while the cash gap in days depicts a negative relationship.

Literature review covers the relationship between liquidity ratios and profitability of firms. It was tried to make it through by covering different reviewing studies of different countries about different sectors and industries at different time periods. Results of the studies are not consistent and there is no any establish theory which can be accepted or rejected by these researches. Review also resulted that impact of liquidity ratios on profitability could vary according to the firm and research technique.

After thorough review of literature, it was found that there is no any study available in the present body of literature which covered automobile industry of Pakistan in terms of liquidity and profitability. This study will fill the gap in the literature and will provide the policy guidelines with empirical evidence for the automobile industry to manage liquidity ratios to a better financial performance.

\section{ECONOMETRIC MODEL AND DATA}

Data of 12 firms for the analysis was fetched from the official website of PSX and it was further validated from the archives of the automobile firms' financial reports. This study covers a period of five years from 2013 to 2017. Five years' data of 12 firms make total 60 observations which is good enough for a panel data analysis (Hasio, 2006; Yaffee, 2003).

$\operatorname{lnRoA} A_{i t}=\beta_{0}+\beta_{1} \operatorname{lnCurRat}{ }_{i t}+\beta_{2} \ln$ QuiRat $_{i t}+\beta_{3} \operatorname{lnCasRat}{ }_{i t}+\beta_{4} X_{i t}+\eta_{i}+\lambda_{t}+\mu_{i t}$

In Eq. (1), i and t denote firm and year, respectively; $\boldsymbol{\beta}_{\mathbf{0}}$ is a constant; $\boldsymbol{\beta}_{\mathbf{1}}-\boldsymbol{\beta}_{\mathbf{3}}$ represents the coefficients to be estimated; $\boldsymbol{\eta}_{\mathbf{i}}$ and $\boldsymbol{\lambda}_{\mathrm{t}}$ stand for the place and time-specific effects, respectively; and $\boldsymbol{\mu}_{\mathbf{i t}}$ refers to a random disturbance term. The variables in the model are as follows:

Explained variable $\ln R o A$ is the natural logarithm of actual return on assets i.e. total revenue divided by total assets. It is adjusted return on assets as both adjusted at the base period of 2013, according to the national price indices of investment in fixed assets. Return on Assets is a measure ratio used for measuring profitability. Profitability refers to the ability of the firm to produce profits by using resources and It shows either resources are in proper use or not (Husna \& Desiyanti, 2016).

\section{Explanatory Variables \\ Current Ratio: -}

Current ratio shows a firm's ability to meet current liabilities with its current assets. Current ratio/ current Liabilities

Cash Ratio:

Cash ratio is the direct and easily liquidness of a firm in order to pay its current debts. Cash + cash equivalents / Current liabilities

Quick Ratio:

The quick ratio emphasizes on the ability of quick assets to pay current liabilities. Current assets - Inventories - prepaid assets/ Current Liabilities. (Robinson et al., 2015).

\section{Region and time effects}

$\eta_{\mathbf{i}}$ denotes the fixed factors that does not vary from time to time in a firm, including geographic location, history and corporate culture. $\lambda_{t}$ stands for the time effect of a firm, e.g. The government policies and macroeconomic situation at different times may affect firms profit significantly. An annual dummy variable is added into the estimation. 
Table 1. Descriptive Statistics

\begin{tabular}{lcccccc}
\hline & $\begin{array}{c}\text { N } \\
\text { Statistic }\end{array}$ & $\begin{array}{c}\text { Minimum } \\
\text { Statistic }\end{array}$ & $\begin{array}{c}\text { Maximum } \\
\text { Statistic }\end{array}$ & $\begin{array}{c}\text { Mean } \\
\text { Statistic }\end{array}$ & $\begin{array}{c}\text { Std.Deviation } \\
\text { Statistic }\end{array}$ & $\begin{array}{c}\text { Skewness } \\
\text { Statistic }\end{array}$ \\
\hline \hline Current Ratio & 60 & .22 & 10.54 & 1.912 & 1.605 & 3.530 \\
Quick Ratio & 60 & .20 & 6.61 & 1.256 & 1.253 & 3.048 \\
Cash Ratio & 60 & .01 & 4.24 & .534 & .721 & 3.267 \\
Return on Assets & 60 & .37 & 53.10 & 13.53 & 11.30 & 1.513 \\
Return on Equity & 60 & .64 & 146.91 & 29.31 & 24.77 & 2.057 \\
Valid N (list wise) & 60 & & & & & \\
\hline
\end{tabular}

\section{Results of model estimation}

Stata 11 statistical package was used to perform the regression in Eq. (1) by employing fixed effect and random effect regression models. Table 2 lists the regression results for the effects of quick ratios on profitability.

All the results of the joint significance test ( $F$ test) with the model indicate that the model is generally effective. When fixed effect and random effect model test are conducted, $\mathrm{p}$ value accompanied in the Hausman test (Table 3) is used to determine whether to choose a fixed or random effect model.

$\mathrm{R}^{2}$ is more than 0.72 in both random and fixed effect regression results, which indicated that the approximately $72 \%$ variance in return on assets (ROA) being explained by the liquidity variables used in this research.

From the random effect model, estimation output the several liquidity independent variables, which include of current ratio, cash ratio, and the quick ratio has the following results:

The positive relationship of current ratio with return on assets (ROA); however, with a p-value of 0.91 , we can equally say that current ratio is insignificantly contributes to return on assets (ROA).

Also, the positive relationship of quick ratio with return on assets (ROA) \& p-value of 0.05 ; hence, we can say that the quick ratio significantly contributes to the return on assets (ROA).

While Cash ratio has a negative relationship with ROA; nevertheless, with a p-value of 0.13 , we can equally say that cash ratio is insignificantly contributes to return on assets (ROA).

Table 2. Results of Fixed Effect and Random Effect $(\mathbf{N}=\mathbf{6 0})$

\begin{tabular}{lccc}
\hline Log of Return In Assets (lnRoA) Dependent Variable & Fixed Effect & Random Effect \\
\hline \hline Log of Current Ratio & lnCurRat & -0.975 & 0.064 \\
Log of Quick Ratio & lnQuiRat & $1.252^{* *}$ & $0.959^{*}$ \\
Log of Cash Ratio & lnCasRat & $-0.464^{* * *}$ & -0.185 \\
& dummy2 & 0.5044 & 0.301 \\
& dummy3 & 0.581 & 0.353 \\
& dummy4 & 0.231 & 0.232 \\
& dummy5 & 0.121 & 0.284 \\
& cons & 1.668 & 1.668 \\
\cline { 2 - 3 } & Rigma_u & 0.75 & 0.72 \\
& sigma_e & 1.238 & .321 \\
& rho & 0.825 & .825 \\
& no: of groups: & 0.692 & 0.131 \\
& Prob $>$ F $=$ & 12 & 12 \\
\hline
\end{tabular}

Note: $* * *, * * *$, represents significance at $10 \%, 5 \%, 1 \%$ level, respectively.

The fixed effect model estimation output the several liquidity independent variables which include of current ratio, cash ratio \& quick ratio has the following results:

Negative relationship of current ratio with return on assets (ROA); however, with a p-value of 0.225 , we can equally say that current ratio has insignificantly contributed to return on assets (ROA). 
Table 3. Hausman Regression Results

\begin{tabular}{|c|c|c|c|c|c|}
\hline variables & & $\begin{array}{l}\text { (b) } \\
\text { Req - fe }\end{array}$ & $\begin{array}{c}\text { (B) } \\
\text { Req-fe }\end{array}$ & $(b-B)$ & $\operatorname{sqrt}\left(\operatorname{dia} \mathrm{q}\left(\mathrm{V}_{-} \mathrm{b}-\mathrm{V}_{-} \mathrm{B}\right)\right)$ \\
\hline Log of Current Ratio & $\operatorname{lnCurRat}$ & -0.975 & 0.0642 & -1.039 & 0.572 \\
\hline Log of Quick Ratio & lnQuiRat & 1.253 & 0.959 & 0.293 & 0.413 \\
\hline \multirow[t]{6}{*}{ Log of Cash Ratio } & lnCasRat & -0.464 & 0.185 & -0.279 & 0.037 \\
\hline & dummy2 & 0.504 & 0.301 & 0.203 & \\
\hline & dummy3 & 0.581 & 0.351 & 0.228 & \\
\hline & dummy4 & 0.231 & 0.232 & -0.001 & \\
\hline & dummy 5 & 0.121 & 0.284 & -0.164 & \\
\hline & \multicolumn{5}{|c|}{$\begin{array}{l}\mathrm{B}=\text { inconsistent under } \mathrm{Ha} \text {, efficient under Ho; obtained from xtreg } \\
\text { Test: Ho: difference in coefficients not systematic } \\
\text { chi2 }(7)=(\mathrm{b}-\mathrm{B}) .\left[\left(\mathrm{V}_{-} \text {b-V_B }\right) \text { A }(-1)\right](\mathrm{b}-\mathrm{B})=\mathbf{5 7 . 1 5} \\
\text { Prob }>\text { chi2 } 2=\mathbf{0 . 0 0 0}\end{array}$} \\
\hline
\end{tabular}

Also, Cash ratio has a statistically significant and negative relationship with ROA; nevertheless, with a pvalue of 0.001 , we can equally say that cash ratio significantly contributes to return on assets (ROA).

While the positive relationship of Quick ratio with return on assets (ROA) \& p-value of 0.058 , hence, we can say that quick ratio significantly contributes to return on assets (ROA).

\section{CONCLUSION}

This study was conducted to investigate the impact of liquidity on the profitability of automobile firms listed in Pakistan stock exchange. Results of the empirical analysis indicate that liquidity has a significant impact on the firm's profitability or no any impact of liquidity on the firm's profitability (return on assets and return on equity), either there is a positive impact of liquidity on firm's profitability or adverse effects of liquidity on firm's profitability.

To measure the financial performance of the firm \& firm's liquidity position by using ratios of liquidity that how performance and profitability of firms increase or decrease by liquidity after researching automobile sector's 12 firms of Pakistan, analyze the impact of liquidity on profitability.

Data gathered systematically from 2013 to 2017. The study of all the 12 automobile firms in Pakistan. Fixed effects, Random effects has been conducted for the evaluation \& analysis of data and Hausman test used in the selection of model. There are three independent variables that were studied (Current ratio, cash ratio, and quick ratio) explain a significant $75 \%$ of profitability of Automobile firms in Pakistan as represented by R Squire $(0.75)$.

The findings indicated that this study established a negative relationship between the liquidity (current ratio) with profitability because current ratio including those current assets which are not easily converted into cash in short-term. Also cash ratio is negative because firms are not earning from those cash which is not invested, it is available for emergency use.

While quick ratio has a positive relationship with profitability (return on assets) of Automobile firms in Pakistan. Quick ratio is positive because quick ratio concludes only those assets which is easily converted into cash in short-term and also indicated that higher liquidity ratios indicates greater liquidity and therefore positively influences firm profitability.

Finally, the study indicated a positive and also a negative significant relationship between liquidity and profitability of the automobile firms in Pakistan. So firms have to increase their performance and profit through improving firm's financial liquidity position and firm's performance. The indications of the results of this research are, firms should utilize current assets at an optimal level in order to get higher profitability.

\section{REFERENCES}

1. Abdullah, M., \& Jahan, N. (2014). The Impact of Liquidity on Profitability in Banking Sector of Bangladesh: A Case of Chittagong Stock Exchange. International Journal of Economic and Business Review e-ISSN: 2347-9671.

2. Ajanthan, A. (2013). A Nexus Between Liquidity \& Profitability: A Study Of Trading Companies In Sri Lanka. European Journal of Business and Management, ISSN 2222-1905.

3. Anzala Noor, \& Samreen Lodhi. (2015). Impact of Liquidity Ratio on Profitability: An Empirical Study of Automobile Sector in Karachi, . International Journal of Scientific and Research Publications, 5(11), ISSN 2250-3153.

4. Balasundaram, D., \& Priya K. (2013). Liquidity Management and Profitability: A Case Study of Listed Manufacturing Companies in Sri Lanka. International Journal of Technological Exploration and Learning (IJTEL), 2(4). 
5. Charmler, R., Musah, A., \& Akomeah, E. (2018). The Impact of Liquidity on Performance of Commercial Banks in Ghana. Academic Journal of Economic Studies, ISSN 2393-4913, ISSN On-line 2457-5836, 4(4), 78-90.

6. Durrah, O., Aziz, A., Rahman, A., Jamil, S., \& Ghafeer, N. (2016). Exploring the Relationship between Liquidity Ratios and Indicators of Financial Performance: An Analytical Study on Food Industrial Companies Listed in Amman Bursa. International Journal of Economics and Financial Issues, 6(2), 435-441.

7. Exchange, P. S. (2013 - 2017). Financial Reports. Retrieved from Pakistan stock exchange Website: https://financials.psx.com.pk/

8. Ghasemi, M., \& Ab Razak, N. H. (2016). The Impact of Liquidity on the Capital Structure: Evidence from Malaysia. International Journal of Economics and Finance; ISSN 1916-971X E-ISSN 1916-9728, $8(10)$.

9. Husna, N., \& Desiyanti, R. (2016). The Analysis of Financial Performance on Net Profit Margin at the Coal Company . International Journal of Management and Applied Science, ISSN: 2394-7926.

10. Hsiao, C. (2007). Panel data analysis - advantages and challenges. Test, 16(1), 1-22.

11. Ibrahim, S. (2017). The Impacts of Liquidity on Profitability in Banking Sectors of Iraq: A Case of Iraqi Commercial Banks. Journal of Finance \& Banking Studies, https://doi.org/10.20525/ijfbs.v6i1.650.

12. khan, R., \& Mutahhar Ali. (2016). Impact of Liquidity on Profitability of Commercial Banks in Pakistan: An Analysis on Banking Sector in Pakistan . Global Journal of Management and Business Research: C Finance.

13. Khidmat, W., \& Rehman, M. (2014). Impact of Liquidity and Solvency on Profitability Chemical Sector of Pakistan. Ekonomika Management Invoice, ISSN: 1804-1299, 6(3).

14. Lartey, V., Antwi, S., \& Boadi , E. (2013). The relationship between liquidity and profitability of listed banks in Ghana. International Journal of Business and Social Science, 4(3), 12-34.

15. Mahmud, K., \& Akhter, A. (2014). Liquidity-Profitability Relationship in Bangladesh Banking Industry. International Journal of Empirical Finance, 2(4), 143-151.

16. Malik, M., Awais, M., \& Khursheed, A. (2016). Impact of Liquidity on Profitability: A Comprehensive Case of Pakistan's Private Banking Sector. International Journal of Economics and Finance.

17. Mathur, S., \& Agarwal , K. (2016). Financial analysis of automobile industries (A comparative study of Tata Motors and Maruti Suzuki). International Journal of Applied Research 2016; 2(9): 533-539.

18. Mohanty, B., \& Mehrotra, S. (2018). Relationship between Liquidity and Profitability: An Exploratory Study of SMEs in India. International Management Institute SAGE Publications sagepub.in/home.nav, DOI: 10.1177/2394901518795069,http://journals.sagepub.com/home/emi.

19. Nazish Bibi, \& Shehla Amjad. (2017). The Relationship between Liquidity and Firms. Asian Journal of Finance \& Accounting, ISSN 1946-052X.

20. Öztürk, H., \& Karabulut, T. (2018). The Relationship between Earnings-to-Price, Current Ratio, Profit Margin and Return: An Empirical Analysis on Istanbul Stock Exchange. Accounting and Finance Research.

21. Paliwal , R., \& Chouhan, V. (2017). Relationship between Liquidity and Profitability in Indian Automobile Industry. International Journal of Science and Research (IJSR ISSN (Online): 2319-7064.

22. Rafiq Ahmad. (2016). A Study of Relationship between Liquidity and Profitability of Standard Charterd Bank Pakistan: Analysis of Financial Statement Approach. Global Journal of Management and Business Research: C Finance Online ISSN: 2249-458.

23. Robinson, T., , Henry, E.,, Pirie, W.,, \& Broihahn, M. (2015). International Financial Statement Analysis (3rd ed.). New Jersey: John Wiley \& Sons, Inc.

24. Ruziqa , A. (2013). The Impact of Credit and Liquidity Risk on Bank Financial Performance: The Case of Indonesian Conventional Bank with Total Asset above 10 trillion Rupiah. International Journals of Economic Policy in Emerging Economies.

25. Sarwat, S. (2017). Impact of Working Capital Management on the Profitability of Firms: Case of Pakistan's Cement Sector. Journal of Advanced Management Science, 5(3).

26. Supriati, D., Ramaditya, M., \& Wardh, N. (2019). Examining the Impact of Leverage and Liquidity on Corporate Performance (A Case Study on Food and Beverage Companies in Indonesia). Advances in Economics, Business and Management Research, Atlantis Press, 73.

27. Umobong, A. (2016). Assessing The Impact of Liquidity And Profitability Ratios On Growth Of Profits In Pharmaceutical Firms In Nigeria. European Journal of Accounting, Auditing and Finance Research, 3(10)

28. Yaffee, R. (2003). A primer for panel data analysis. Connect: Information Technology at NYU, 1-11. 